\title{
Lhermitte's sign and vitamin B12 deficiency: case report
}

Sinal de Lhermitte e deficiência de vitamina B12: relato de caso

\author{
Hélio Afonso Ghizoni Teive ${ }^{1}$, Salo Haratz² , Jorge Zavala² ${ }^{2}$ Renato Puppi Munhoz ${ }^{3}$, Rosana Hermínia Scola ${ }^{1}$, Lineu César Werneck \\ Neurology Outpatient Clinic, Neurology Service, Department of Internal Medicine, Hospital de Clínicas, Universidade Federal do Paraná (UFPR), Curitiba, Paraná, Brazil
}

\section{KEY WORDS:}

Myelopathy.

Vitamin B12 deficiency.

Ataxia.

Aged.

Polyneuropathies.

\section{PALAVRAS-CHAVE:}

Mielopatia.

Deficiência de vitamina B12.

Ataxia.

Idoso.

Polineuropatias.

\section{ABSTRACT}

CONTEXT AND OBJECTIVE: Lhermitte's sign, a classical neurological sign, is a rare manifestation of vitamin B12 deficiency. The aim here was to report on a case of an elderly patient with vitamin B12 deficiency whose first clinical manifestation was the presence of Lhermitte's sign.

CASE REPORT: We describe an elderly patient with vitamin B12 deficiency who presented cognitive dysfunction, peripheral polyneuropathy and sensory ataxia, and whose first clinical manifestation was the presence of Lhermitte's sign. This sign is one of the rarest manifestations of vitamin B12 deficiency.

\section{RESUMO}

CONTEXTO E OBJETIVO: 0 sinal de Lhermitte, um sinal neurológico clássico, é uma rara manifestação clínica da deficiência de vitamina B12. 0 objetivo foi relatar o caso de um paciente idoso com deficiência de vitamina B12, cuja manifestação clínica inicial foi a presença do sinal de Lhermitte.

RELATO DO CASO: Paciente idoso com deficiência de vitamina B12, apresentou-se com disfunção cognitiva, polineuropatia periférica e ataxia sensitiva, cuja manifestação clínica inicial foi a presença do sinal de Lhermitte. Este sinal é uma das mais raras manifestações da deficiência de vitamina B12. 


\section{INTRODUCTION}

Vitamin B12 deficiency is found in 15\% of the geriatric population. The manifestations are hematological, gastrointestinal and neuropsychiatric., ${ }^{1,2}$ The neurological manifestation consists of subacute combined degeneration of the spinal cord that is clinically characterized by sensory ataxia, peripheral neuropathy, cognitive dysfunction and optic neuropathy. ${ }^{1,2}$

Lhermitte's sign, also known as the barber's shop sign, is more properly a symptom than a sign, and is described by patients as an electriclike sensation induced by forward flexion of the head. ${ }^{3,4}$ It was originally described by Marie and Chatelin in 1917, and one year later by Babinski and Dubois. The importance of this phenomenon was defined by the classical description by Jean L. Lhermitte in 1924 on a case of multiple sclerosis. ${ }^{5-8}$ One patient described it as follows: "When I bent my head, I felt a violent shock in my neck and a pain like an electric current running through my whole body, from the neck down the vertebral column into the feet". 8

The presence of Lhermitte's sign is a rare manifestation..$^{3-8}$ To estimate the validity and frequency of this sign for diagnosing myelopathy, we conducted a systematic review of the literature, including the following databases: DotLib - OVID; DotLib - OVID (Lippincott); EBSCO Biomedical Reference Collection; EBSCO - MedicLatina; EBSCO - Medical Literature Analysis and Retrieval System Online (Medline); ProQuest - Medical Library; PubMed; Cochrane Library; and Literatura Latino-Americana e do Caribe em Ciências da Saúde (Lilacs). Using the Medical Subject Headings/Descritores em Ciências da Saúde (MeSH/ DeCS) terminology (Lhermitte AND Sign) we found, as shown in Table 1 , that most studies reported to date are either in the form of case reports or demonstrate several procedural biases that may distort the accuracy values. ${ }^{9-18}$ Only two studies measured the diagnostic accuracy of Lhermitte's sign, and they found that its sensitivity is markedly poor, ranging from 3 to $17 \%{ }^{19,20}$ One of these studies also found that it presented good specificity (97\%) for nonspecific compressive myelopathy. ${ }^{20}$

We describe an elderly patient with vitamin B12 deficiency who initially presented with Lhermitte's sign.

\section{CASE REPORT}

A 68-year-old man came to the outpatient clinic reporting an electric shock-like sensation through his neck and spreading down his spine and lower limbs that was triggered by neck flexion. This was associated with paresthesia in his toes, gait disorders, progressive memory loss and slow thinking that had also been noticed over a three-month period preceding the appointment.

The examination on the patient revealed cognitive dysfunction (mini-mental state examination, MMSE $=18 / 30$ ), glove and stocking hypoesthesia, proprioception loss in the lower limbs, wide-based gait and Romberg's and Lhermitte's signs. The cranial nerves, motor strength, muscle tone, coordination, muscle strength reflexes and plantar reflex were normal. Laboratory investigation revealed macrocystic anemia. The creatinine levels, liver function, blood electrolytes, coagulation profile and thyroid-stimulating hormone (TSH) were normal. The erythrocyte sedimentation rate (ESR) was $54 \mathrm{~mm} / \mathrm{h}$. The serum vitamin B12 level was $51 \mathrm{pg} / \mathrm{ml}$ (normal range $=200-900 \mathrm{pg} / \mathrm{ml}$ ). The cerebrospinal fluid was normal with negative venereal disease research laboratory (VDRL) and anti-human immunodeficiency virus (anti-HIV) antibodies. A hiatus hernia and a gastric polyp were seen on gastroscopy. Histopathology was negative for malignancies. Nerve conduction evaluation revealed axonal sensory-motor peripheral polyneuropathy. Brain and spinal cord magnetic resonance imaging (MRI) were normal.

Intramuscular vitamin B12 therapy was started (5000 IU, monthly). Complete recovery was progressively achieved over a 12 -month period.

\section{DISCUSSION}

The neurological manifestations of vitamin B12 deficiency include peripheral and cranial nerve neuropathy and spinal cord and brain syndromes. ${ }^{1,2}$ Healton et al. found neurological signs in $74 \%$ of 143 vitamin B12 deficiency patients. Their findings were peripheral neuropathy (25\%) myelopathy (12\%), a combination of both of these $(41 \%)$, neuropsychiatric dysfunction $(8.1 \%)$ and visual deficits $(0.5 \%){ }^{1}$ The presence of Lhermitte's sign in patients with vitamin B12 deficiency has been previously described, ${ }^{3-7}$ and it is characterized by a sensation of electrical lightning discharge, with paresthesia experienced through the spine, legs and sometimes arms, caused by neck flexion. ${ }^{8}$

The pathophysiology of Lhermitte's sign was classically described as related to the stretching of the hyperexcitable demyelinated dorsal column of the spinal cord, particularly at the cervical level, thereby triggering an electric shock-like sensation. ${ }^{4,8}$ Today, hyperexcitability is still regarded as the main pathophysiological mechanism. Moreover, from an

Table 1. Published articles on Lhermitte's sign

\begin{tabular}{|c|c|c|}
\hline Database & Search strategy & Results \\
\hline DotLib - OVID & Lhermitte AND sign & 3 reviews; 78 case series/reports \\
\hline DotLib - OVID (Lippincott) & Lhermitte AND sign & 4 reviews; 78 case series/reports \\
\hline EBSCO - Biomedical Reference Collection & Lhermitte AND sign & 1 review; 37 case series/reports \\
\hline EBSCO - MedicLatina & Lhermitte AND sinal & 6 case reports \\
\hline EBSCO - Medline & Lhermitte [MeSH] AND sign [MeSH] & 52 reviews; 945 case series/reports \\
\hline ProQuest - Medical Library & Lhermitte [MeSH] AND sign [MeSH] & 2 reviews; 42 case series/reports \\
\hline PubMed & Lhermitte [MeSH] AND sign [MeSH] & 52 reviews; 830 case series/reports \\
\hline Cochrane & Lhermitte [MeSH] AND sign [MeSH] & 2 reviews \\
\hline Lilacs & Lhermitte [DeCS] AND sinal [DeCS] & 20 case series/reports \\
\hline
\end{tabular}

Medline = Medical Literature Analysis and Retrieval System Online; Lilacs = Literatura Latino-Americana e do Caribe em Ciências da Saúde; MeSH = Medical Subject Headings; DeCS = Descritores em Ciências da Saúde. 
etiological standpoint, in the original paper by Lhermitte, the shock-like sensations were attributed to medullar lesions due to demyelination or trauma of the dorsal column. . $^{1,4,8,21}$

Since then, although the presence of Lhermitte's sign remains associated with such causes, particularly multiple sclerosis, several other causes have been described, including cervical disc hernia, cervical spondylosis, tumors, radiation myelopathy, herpes zoster, arachnoiditis, Behcet's disease, atlantoaxial subluxation, and non-lesional disorders such as hyperexcitability of the ascending sensory neurons of the posterior column due to toxic causes. ${ }^{4,8,22}$

Increased T2-weighted and decreased T1-weighted signals, with contrast enhancement in the posterior and lateral columns of the spinal cord can be revealed by MRI. ${ }^{21-23}$

Lhermitte's sign is rare in patients with vitamin B12 deficiency and may improve with specific therapy.

\section{REFERENCES}

1. Healton EB, Savage DG, Brust JC, Garrett TJ, Lindenbaum J. Neurologic aspects of cobalamin deficiency. Medicine (Baltimore). 1991;70(4):229-45

2. Green R, Kinsella L. Current concepts in the diagnosis of cobalamin deficiency. Neurology. 1995;45(8):1435-40.

3. Gautier-Smith PC. Lhermitte's sign in subacute combined degeneration of the cord. J Neurol Neurosurg Psychiatry. 1973;36(5):861-3.

4. Kempster PA, Rollinson RD. The Lhermitte phenomenon: variant forms and their significance. J Clin Neurosci. 2008;15(4):379-81.

5. Butler WM, Taylor HG, Diehl LF. Lhermitte's sign in cobalamin (vitamin B12) deficiency. JAMA. 1981;245(10):1059.

6. Sandyk R, Brennan JW. “Lhermitte's sign” as a presenting symptom of subacute combined degeneration of the cord. Ann Neurol. 1983;13(2):215-6

7. Weeks RA, Valentine A, Savy L, Wilson LA. Mild tactile disturbance and a Ihermitte phenomenon in a middle-aged man. Arch Neurol. 1999;56(12):1515-6.

8. Frederiks JAM. Lhermitte's sign. In: Koehler PJ, Bruyn GW, Pearce JMS, editors. Neurological eponyms. Oxford: Oxford University Press; 2000. p. 106-10.

9. Castaigne P, Lhermitte F, Escourolle R, Hauw JJ, Gray F, Lyon-Caen O. Les scleroses en plaques asymptomatiques [Asymptomatic multiple sclerosis- 3 cases]. Rev Neurol (Paris). 1981;137(12):729-39.

10. García-Moreno JM, Izquierdo G. Signo de Lhermitte. [Lhermitte's sign]. Neurologia. 2002;17(3):143-50.
11. Cook CE, Hegedus E, Pietrobon R, Goode A. A pragmatic neurological screen for patients with suspected cord compressive myelopathy. Phys Ther. 2007;87(9):1233-42.

12. Imai T, Tsuda E, Suzuki M, Hozuki T, Matsumoto H. Lhermitte's sign in alcoholic myelopathy without portosystemic shunting: MRI evaluation. Intern Med. 2005;44(2): 153-4.

13. Klimo P Jr, Blumenthal DT, Couldwell WT. Congenital partial aplasia of the posterio arch of the atlas causing myelopathy: case report and review of the literature. Spine. 2003;28(12):E224-8.

14. Taieb S, Trillet-Lenoir V, Rambaud L, Descos L, Freyer G. Lhermitte sign and urinary retention: atypical presentation of oxaliplatin neurotoxicity in four patients. Cancer. 2002;94(9): 2434-40.

15. Ciucci G, De Giorgi U, Leoni M, Bianchedi G. Lhermitte's sign following oxaliplatincontaining chemotherapy in a cisplatin-pretreated ovarian cancer patient. Eur J Neurol 2003;10(3):328-9

16. Anderson FH, Lehrich JR. Lhermitte sign following head injury. Arch Neurol. 1973; 29(6):437-8

17. Layzer RB. Myeloneuropathy after prolonged exposure to nitrous oxide. Lancet. 1978; 2(8102):1227-30

18. Leung WM, Tsang NM, Chang F, Lo CJ. Lhermitte's sign among nasopharyngeal cancer patients after radiotherapy. Head Neck. 2005;27(3):187-94.

19. Crandall PH, Batzdorf U. Cervical spondylotic myelopathy. J Neurosurg 1966;25:57-66.

20. Uchihara T, Furukawa T, Tsukagoshi H. Compression of brachial plexus as a diagnostic test of cervical cord lesion. Spine. 1994;19(19):2170-3

21. Karacostas D, Artemis N, Bairactaris C, Tsitourides I, Milonas I. Cobalamin deficiency: MRI detection of posterior columns involvement and posttreatment resolution. J Neuroimaging. 1998;8(3):171-3

22. Misra UK, Kalita J, Das A. Vitamin B12 deficiency neurological syndromes: a clinical, MR and electrodiagnostic study. Electromyogr Clin Neurophysiol. 2003;43(1):57-64.

23. Fritschi J, Sturzenegger M. Spinal MRI supporting myelopathic origin of early symptoms in unsuspected cobalamin deficiency. Eur Neurol. 2003;49(3):146-50.

Sources of funding: Not declared

Conflict of interest: Not declared

Date of first submission: October 10, 2007

Last received: June 25, 2009

Accepted: August 5, 2009

Address for correspondence:

Hélio Afonso Ghizoni Teive

Rua General Carneiro, 1.103 - Apto. 102

Centro - Curitiba (PR) - Brasil

CEP 80060-150

Tel./Fax. (+ 55 41) 3019-5060

E-mail: hagteive@mps.com.br 